\title{
A COMPARATIVE STUDY OF CHEMICAL COMPOSITION OF ACACIA SEYAL STEM, STEM WOOD AND STEM BARK DRY DISTILLATES USED BY SUDANESES WOMEN AS COSMETIC AND MEDICINE
}

\author{
IKRAM MOHAMED ELTAYEB ${ }^{*}$, ITMAD AWAD ELHASSAN², JIHAD HASAB ELRASOUL ${ }^{1}$, EIMAN SALAH ELDIN1 \\ ${ }^{1}$ Department of Pharmacognosy, Faculty of Pharmacy, University of Medical Sciences and Technology, Khartoum, Sudan, ${ }^{2}$ Pharmaceutical \\ Industries Department, Industrial Research and Consultancy Centre, Ministry of Science and Technology, Khartoum, Sudan \\ Email: kramela_07@yahoo.com \\ Received: 03 Aug 2017 Revised and Accepted: 21 Sep 2017
}

\begin{abstract}
Objective: The content and chemical composition of dry distillates of the stem, stem wood and stem bark of Acacia seyal were investigated. The distillates are fumigants of $A$. seyal locally known in Sudan as Dokhan and widely used for its cosmetic, aromatic and medicinal value for the treatment of candidiasis, genital yeast infection, urinary tract infection, diarrhoea, respiratory tract infection, skin infection and with potent, antioxidant and antimicrobial activities.

Methods: The dry distillates were prepared by dry distillation method from the Acacia seyal stem, stem wood and stem bark and investigated chemically by GC-MS analysis.

Results: The percentage yield of dry distillates (Dokhan) wer found to be $4.0 \%, 4.8 \%, 1.4 .1 \% \mathrm{v} / \mathrm{w}$ for stem, stem wood and stem bark respectively. GC-MS analysis revealed the presence of one hundred and twenty three constituents in the stem distillate with major constituents of solerone (7.27\%), furfural (7.15\%), catechol (7.11\%), syringol (5.56\%), allo-inositol (4.86\%), mequinol (4.81\%), furfuralcohol (3.35\%), 3-methyl-1,2cyclopentanedione $(3.24 \%)$, phenol $(2.73 \%)$, homovanillyl alcohol $(2.56 \%)$ and 3-cresol $(2.11 \%)$. the wood distillate show detection of eighty compounds, with main compounds: 1, 3-dimethyl-5-methoxypyrazol (10.61\%), syringol (6.75\%), furfuralcohol (5.24\%), mequinol (4.49\%), 1,2anhydro-3,4,5,6-alloinositol (4.26\%), 3-methyl-1,2-cyclopentanedione (3.42\%), catechol (3.37\%), 3-methoxycatechol (3.22\%), homovanillyl alcohol (2.78\%), homosyringic acid (2.40\%), 3-cresol (2.18\%), 3-methyl-2-cyclopentenone (2.44\%) and 1,2-cyclopentanedione (2.03\%). Sixty six compounds were detected in the distillate bark and the main compounds were found to be hexadecanoic $(62.83 \%)$, catechol (3.38\%), tetrapentacontane (3.18\%), phenol (2.72\%), mequinol (2.30\%) and 2-ethylfurane $(2.22 \%)$.
\end{abstract}

Conclusion: The result concludes that the medicinal Sudanese Dokhan have good potential as sources of different bioactive compounds and antioxidants.

Keywords: Chemical composition, Dry distillates, Acacia, seyal, Stem, Stem wood, Stem bark

(C) 2017 The Authors. Published by Innovare Academic Sciences Pvt Ltd. This is an open access article under the CC BY license (http://creativecommons.org/licenses/by/4.0/) DOI: http://dx.doi.org/10.22159/ijpps.2017v9i11.21802

\section{INTRODUCTION}

Acacia seyal (Fabaceae) is a small to a medium important tree in Sudan, locally known as Talih. The pleasantly fragrant fumigate of the stem or stem wood, known as Dokhan is widely used by Sudanese women as an aromatic and medicinal plant for cleanness and perfume purposes. Dokhan from the stem or stem wood was known for its potent antimicrobial and antioxidant activity]. The aromatic oil from the plant traditionally used by Sudanese women showed preservative and therapeutic properties in addition to its pleasant aroma [1-7].

The Fabaceae family produces more nitrogen-containing secondary metabolites than other plant families such as quinolizidine, pyrrolizidine, indolizidine, piperidine, pyridine, pyrrolidine and many other nitrogenous compounds [8]. Acacia genus was reported to have many secondary metabolites such as amines, alkaloids, cyanogenic glycosides, cyclitols, fatty acids and seed oils, fluoroacetate, amino acids, essential oils, diterpenes, phytosterol, triterpenes, saponins and hydrolyzable tannins. The most evident and best known are polysaccharides (gums) and complex phenolic substances (condensed tannins) [9]. A. seyal is highly nitrogen-fixing and moderately salt tolerant species and characterized by high content of proteins, phenols and flavonoids [10].

The present paper represents the first attempt to investigate and compare of the content and composition of the dry distillates (Dokhan) of A. seyal stem, stem wood and stem bark with potent antioxidant and antimicrobial activities [1] which is traditionally used by Sudanese women for cosmetic and therapeutic purposes mainly for the treatment of candidiasis, genital yeast infection, urinary tract infection, severe stomach cramps, diarrhea, vomiting, respiratory tract disease, cold and throat infection, wound and skin infection and toothache $[1,11]$.

\section{MATERIALS AND METHODS \\ Plant materials collection and preparation}

The stem of $A$. seyal was collected from Omdurman local market Sudan, and then it was authenticated by taxonomist at the Department of Silviculture, Faculty of Forestry, University of Khartoum. The voucher specimen; IKR4, December-2015 was deposited at the Department of Pharmacognosy, Faculty of Pharmacy, University of Medical Science and Technology. The collected material was cleaned, dried and separated into two parts: one part of the plant material was chopped into small pieces and the other was separated into stem bark and stem wood and they were preserved separately for further studies.

\section{Phytochemical screening}

The phytochemical constituents of the plant material were detected using a standard procedure described by Farhat et al., et al., [12], Prashant et al., [13] and Mosa et al., [14]. The physiochemical parameters of the plant materials were detected according to the methods described by the WHO [(15].

Distillates preparation and determination of physiochemical properties

The stem, stem wood and stem bark distillates were prepared from the samples by dry distillation technique described by lewandowki and Milchert [16] with a minor modification. The percentage yield 
was determined in $(\mathrm{v} / \mathrm{w})$ and $(\mathrm{w} / \mathrm{w})$ with reference to the dried sample weight.

Solubility, specific gravity, refractive index, acid value, ester value and a saponification value of the prepared distillates were determined according to the British Pharmacopoeia, $(2002)[17,18]$.

\section{GC-MS analysis}

The gas chromatography-Mass spectrometry analysis was carried out on gas chromatograph coupled to a mass spectrometer (GC-MS QP). The temperature was programmed at $180^{\circ} \mathrm{C}$ for $2 \mathrm{~min}$. at a rate of $10 \mathrm{c} / \mathrm{min}$, and then increased to $289^{\circ} \mathrm{C}$ for $1 \mathrm{~min}$. at a rate of $15 \mathrm{c} / \mathrm{min}$ and the dry distillate was injected with split injection mode. The identification of different components was achieved from their mass spectra, retention time (RT), compared to those in NIST library [19]. The fragmentation mode of major constituents was carried out and their $\mathrm{m} / \mathrm{z}$ value was compared with those obtained in the Mass spectrometry spectra.

\section{RESULTS}

\section{Phytochemical screening}

The phytochemical screening of $A$. seyal stem, stem wood and stem bark (table 1) revealed the presence of tannuns, terpenoids, cardiac glycoside and reducing sugar in the three assessed materials. Flavonoids, alkaloids and steroids are detected in the stem and stem wood, whereas, they are absence in the stem bark. Saponnins are not detected in any of the three plant materials.

Percentage yields and physiochemical properties of the distillates

The oily dry distillates of $A$. seyal stem, stem wood and stem bark were found to be slightly different in their physiochemical properties. The physiochemical property of stem bark is more differ from that of stem and stem wood (table 2).

Table 1: Qualitative phytochemical screening of $A$. seyal stem, stem wood and stem bark

\begin{tabular}{|c|c|c|c|}
\hline \multirow[t]{2}{*}{ Phytochemical } & \multicolumn{3}{|c|}{ Result } \\
\hline & Stem & Wood & Bark \\
\hline Flavoniods & +ve & $+\mathrm{ve}$ & -ve \\
\hline Alkaloids & +ve & + ve & -ve \\
\hline Tannins & +ve & $+\mathrm{ve}$ & + ve \\
\hline Saponins & -ve & -ve & -ve \\
\hline Steroids & +ve & + ve & -ve \\
\hline Terpenoids & +ve & $+\mathrm{ve}$ & $+\mathrm{ve}$ \\
\hline Cardiac glycosides & + ve & $+\mathrm{ve}$ & + ve \\
\hline Reducing sugars & $+\mathrm{ve}$ & $+\mathrm{ve}$ & +ve \\
\hline
\end{tabular}

+: presence,-: absence

Table 2: Percentage yields and physiochemical properties of dry distillates of $A$. seyal stem, wood and stem bark

\begin{tabular}{lllllll}
\hline Plant part & \multicolumn{2}{l}{ Percentage yield } & \multicolumn{2}{l}{ Physiochemical } & & Es. V \\
\cline { 2 - 7 } & V/W & W/W & Sp. Gr. & Ref. I & Ac. V. & Sap. V \\
\hline Stem & $15 \%$ & $83.8 \%$ & $0.95 \mathrm{~g}$ & 1.341 & $23.6 \mathrm{ml} / \mathrm{g}$ & $34.8 \mathrm{ml} / \mathrm{g}$ \\
Stem wood & $14.1 \%$ & $48 \%$ & $0.95 \mathrm{~g}$ & 1.352 & $24.6 \mathrm{ml} / \mathrm{g}$ & $34.8 \mathrm{ml} / \mathrm{g}$ \\
Stem bark & $13.6 \%$ & $53 \%$ & $0.95 \mathrm{~g}$ & 1.341 & $21.7 \mathrm{ml} / \mathrm{g}$ & $16.1 \mathrm{ml} / \mathrm{g}$ \\
\hline
\end{tabular}

$\mathrm{V} / \mathrm{M}=$ volume/weight, $\mathrm{W} / \mathrm{W}=$ weight/weight, Sp. Gr.= specific gravity, Ref. I = refractive index, Ac. V= acid value, Es. V. = ester value, Sap. $\mathrm{V} .=$ saponification value

\section{GC-MS analysis}

The results of GC-MS analysis of the distillates showed a slight difference between the chemical constituents of stem and stem wood distillates, whereas, the chemical constituent of stem bark distillate is more different from those two distillates. The analysis revealed the presence of one hundred and twenty-three, eighty and sixty-six constituents of the stem, stem wood and stem bark distillates respectively (table 3 and fig. 1, 2, 3, 4).

Table 3: GC-MS result of $A$. seyal stem, stem wood and stem bark dry distillates

\begin{tabular}{|c|c|c|c|c|c|}
\hline \multirow[t]{2}{*}{ Compound number } & \multirow[t]{2}{*}{ R. T } & \multirow[t]{2}{*}{ Compound name } & \multicolumn{3}{|c|}{ Area \% } \\
\hline & & & Stem & Wood & Bark \\
\hline 1 & 3.034 & Propanal & - & 0.85 & - \\
\hline 2 & 3.090 & Propanoic acid & - & - & 0.11 \\
\hline 3 & 3.090 & Butanoic acid & - & 0.85 & 0.24 \\
\hline 4 & 3.090 & Quinone & - & - & 0.07 \\
\hline 5 & 3.100 & Pyridine,3-methyl & - & - & 0.23 \\
\hline 6 & 3.102 & Furfural & 7.15 & 0.22 & - \\
\hline 7 & 3.236 & Methylthiirane & 0.13 & - & - \\
\hline 8 & 3.317 & Furfuralcohol & 3.35 & 5.24 & 1.47 \\
\hline 9 & 3.449 & Unknown & 0.76 & - & - \\
\hline 10 & 3.581 & Aniline & - & - & 0.47 \\
\hline 11 & 3.581 & (S)-5-Hydroxymethyl-2-(5H)-furanone & - & 0.07 & - \\
\hline 12 & 3.628 & 4-Methylhexanoic acid & 0.12 & - & - \\
\hline 13 & 3.662 & Avitrol & - & - & 0.18 \\
\hline 14 & 3.662 & 2,3-Pentanediol & - & 0.35 & - \\
\hline 15 & 3.836 & 2-(Tetrahydrofuran-2-yloxy)-ethanol & 0.11 & 0.52 & - \\
\hline 16 & 3.915 & dl-Threonine & 0.64 & - & - \\
\hline 17 & 3.991 & 2-Ethylfurane & 1.15 & 1.75 & 2.22 \\
\hline
\end{tabular}




\begin{tabular}{|c|c|c|c|c|c|}
\hline 18 & 4.041 & 1, 3-Dimethyl-5-methoxypyrazol & - & 10.61 & - \\
\hline 19 & 4.045 & 2-Acetylfuran & 0.66 & 0.73 & 0.46 \\
\hline 20 & 4.088 & Dumasin & 1.51 & 0.97 & - \\
\hline 21 & 4.134 & 2-Cyclohexenol & 0.13 & - & - \\
\hline 22 & 4.209 & 1,2-cyclopentanedione & 1.28 & 2.03 & 0.15 \\
\hline 23 & 4.245 & $\beta$-Octalactone & 0.12 & 0.38 & - \\
\hline 24 & 4.332 & 3,5-Lutidine & 0.14 & - & 0.10 \\
\hline 25 & 4.334 & Angelica lactone & - & 0.42 & 0.08 \\
\hline 26 & 4.340 & 4-Methyl-2(5H)-furanone & - & - & 0.10 \\
\hline 27 & 4.350 & L-Leucine,ethyl ester & - & 0.45 & 0.35 \\
\hline 28 & 4.365 & 2-Cyclohexenone & 0.09 & 0.16 & 0.79 \\
\hline 29 & 4.427 & 6-Methyl-2,2-diphenyl-cyclohexanone & 0.42 & 0.30 & - \\
\hline 30 & 4.533 & Suberone & 0.23 & - & 0.42 \\
\hline 31 & 4.640 & Valerolactone & 0.08 & - & - \\
\hline 32 & 4.694 & Ethylene dipropionate & 0.42 & - & - \\
\hline 33 & 4.740 & $\gamma$-Ethoxybutyrolactone & 0.16 & - & - \\
\hline 34 & 4.770 & 5-methylfurfural & 0.46 & - & - \\
\hline 35 & 4.805 & 3-Methyl-2-cyclopentenone & 1.03 & 2.44 & 1.07 \\
\hline 36 & 4.874 & Octanamide & - & 0.43 & - \\
\hline 37 & 4.893 & Hexanoic acid & 0.08 & 1.42 & - \\
\hline 38 & 4.936 & Methyl 2-furoate & 0.09 & - & 0.06 \\
\hline 39 & 4.975 & Phenol & 2.73 & 1.79 & 2.72 \\
\hline 40 & 5.088 & Maleamic acid & 0.12 & 0.72 & - \\
\hline 41 & 5.137 & 2 -Hydroxy- $\gamma$ butyrolactone & 0.44 & - & - \\
\hline 42 & 5.221 & 3,4-dimethylcyclopent-2-en-1-one & 0.21 & - & 0.41 \\
\hline 43 & 5.231 & $\gamma$-Crotolactone & - & 1.50 & 0.28 \\
\hline 44 & 5.289 & Decylamide & 0.82 & - & - \\
\hline 45 & 5.328 & 2,3-Dimethylpyrazine & - & - & 0.04 \\
\hline 46 & 5.329 & 3,5-Dimethyl-2(5H)-furanone & 0.51 & 0.42 & 0.22 \\
\hline 47 & 5.400 & Tetrahydro, furfuryl alcohol & 0.81 & 0.89 & 0.43 \\
\hline 48 & 5.515 & Unknown & - & - & 0.27 \\
\hline 49 & 5.515 & Uridine & 0.33 & 0.15 & \\
\hline 50 & 5.651 & 4-methyl-4-Hepten-3-ol & 0.27 & - & - \\
\hline 51 & 5.724 & 3-Methyl-1,2-cyclopentanedione & 3.24 & 3.42 & 0.58 \\
\hline 52 & 5.864 & 2,3,4,5-Tetramethylfuran & 0.12 & - & 0.06 \\
\hline 53 & 5.865 & Methyl 3-butenoate & - & - & 0.17 \\
\hline 54 & 5.890 & Dihydro-2-methyl-3-furanone & - & - & 0.13 \\
\hline 55 & 5.905 & 3-Ethylpyridine & - & - & 0.06 \\
\hline 56 & 5.927 & 2,3-dimethyl-2-cyclopentenone & 0.99 & 0.73 & 0.14 \\
\hline 57 & 6.002 & 4-Methyl-2(5H)-furanone & 0.22 & 0.34 & - \\
\hline 58 & 6.103 & Orthocresol & 0.98 & 1.66 & 0.75 \\
\hline 59 & 6.150 & 3-Ethyl-2-hydroxy-2-cyclopenten-1-one & 0.30 & 0.85 & 0.36 \\
\hline 60 & 6.226 & 2-Acetylpyrrole & 0.09 & - & 0.06 \\
\hline 61 & 6.281 & 2-Hexyltetrahydrofuran & 0.45 & - & - \\
\hline 62 & 6.361 & Heptanoic acid & 0.21 & 0.12 & - \\
\hline 63 & 6.414 & 3-Cresol & 2.11 & 2.18 & 1.50 \\
\hline 64 & 6.466 & Thymine & - & 0.20 & - \\
\hline 65 & 6.489 & Octanal & 0.32 & - & - \\
\hline 66 & 6.598 & $\gamma$-tridecalactone & 0.06 & 1.43 & - \\
\hline 67 & 6.640 & 15-Amino-1-pentanol, N,0-diacetyl- & 0.09 & - & - \\
\hline 68 & 6.707 & Mequinol & 4.81 & 4.49 & 2.30 \\
\hline 69 & 6.783 & 2-Octenal & 1.56 & - & - \\
\hline 70 & 6.876 & 4-Pyridinol & 1.31 & & 0.65 \\
\hline 71 & 6.951 & 1-(2-furyl)pyrrole & - & 1.12 & - \\
\hline 72 & 6.954 & 4-Octyne & - & - & 0.19 \\
\hline 73 & 6.960 & 2,6-Dimethylphenol & 0.22 & - & - \\
\hline 74 & 7.064 & Maltol & 0.53 & 0.51 & 0.25 \\
\hline 75 & 7.153 & 2-Isopropyl-2,5-dimethyl-cyclohexanone & 0.95 & - & - \\
\hline 76 & 7.316 & 2-Ethyl-6-methylpyridine & - & - & 0.12 \\
\hline 77 & 7.382 & Cyclohexane & 0.23 & - & - \\
\hline 78 & 7.449 & 2-Octyne & - & 0.21 & 0.07 \\
\hline 79 & 7.571 & p-Xylenol & 0.92 & 0.57 & 0.20 \\
\hline 80 & 7.685 & Diethyl azodicarboxylate & 0.28 & - & - \\
\hline 81 & 7.758 & Benzoic acid & 0.12 & - & - \\
\hline 82 & 7.832 & Octanoic acid & 0.46 & 0.07 & - \\
\hline 83 & 7.866 & Meobal & 0.56 & - & - \\
\hline 84 & 8.031 & Phenylethyl Alcohol & 0.08 & - & 0.07 \\
\hline 85 & 8.088 & Creosol & 0.24 & 1.92 & 0.43 \\
\hline 86 & 8.230 & Tetrahydro-2-Furancarboxylic acid & 0.92 & 0.44 & - \\
\hline 87 & 8.332 & Catechol & 7.11 & 3.37 & 3.38 \\
\hline 88 & 8.567 & 3-Hexenedioic acid, trans- & 1.15 & 1.36 & 0.53 \\
\hline 89 & 8.625 & methyl salicylate & 0.07 & - & - \\
\hline 90 & 8.783 & Thiophene,2-propyl & 0.24 & - & - \\
\hline 91 & 8.849 & DL-Lactide & 0.53 & - & - \\
\hline
\end{tabular}




\begin{tabular}{|c|c|c|c|c|c|}
\hline 92 & 8.945 & Camphor & 0.20 & - & - \\
\hline 93 & 9.065 & Di-n-butyl diazene, & - & 1.70 & \\
\hline 94 & 9.123 & Phorone & 0.09 & - & - \\
\hline 95 & 9.172 & Threitol, acetylated & 0.09 & - & - \\
\hline 96 & 9.282 & 2-Methyl hydroquinone & 0.57 & 0.71 & - \\
\hline 97 & 9.356 & 3-Methoxycatechol & 1.80 & 3.22 & 0.23 \\
\hline 98 & 9.440 & Hydroquinone & 1.03 & 0.90 & 0.49 \\
\hline 99 & 9.600 & 4-Ethylguaiacol & 1.21 & 1.20 & 0.25 \\
\hline 100 & 9.703 & Orcinol & 1.56 & 1.23 & 0.45 \\
\hline 101 & 9.789 & Solerone & 7.27 & - & 0.12 \\
\hline 102 & 9.876 & Lactide & 0.20 & - & - \\
\hline 103 & 10.121 & 4-Vinylguaiacol & 0.68 & 0.75 & 0.58 \\
\hline 104 & 10.249 & 4-Butoxy-1-butanol & 0.23 & - & - \\
\hline 105 & 10.345 & L-Glutamine & - & 0.59 & - \\
\hline 106 & 10.484 & 4-Methylcatechol & 0.87 & - & 0.56 \\
\hline 107 & 10.558 & Propylthiophene & 0.19 & - & - \\
\hline 108 & 10.646 & Syringol & 5.56 & 6.75 & 0.83 \\
\hline 109 & 10.678 & 2,3-Xylenol & - & 0.54 & 0.13 \\
\hline 110 & 10.740 & Eugenol & 0.14 & 0.26 & - \\
\hline 111 & 10.796 & 3,4-Dimethoxyphenol & 032 & - & - \\
\hline 112 & 10.876 & Dihydroeugenol & 0.26 & 0.22 & - \\
\hline 113 & 10.975 & 3,7,11,15-Tetramethyl-1-hexadecyn-3-ol & 0.08 & - & - \\
\hline 114 & 11.052 & 4-Ethylcatechol & 0.68 & 0.49 & - \\
\hline 115 & 11.092 & (E)-Dodec-2-enyl ethyl carbonate & - & 0.46 & - \\
\hline 116 & 11.092 & Unknown & - & - & 0.50 \\
\hline 117 & 11.233 & 2,3,5-Trimethylphenol & 0.07 & - & - \\
\hline 118 & 11.285 & 4-Methoxythiophenol & 0.14 & - & - \\
\hline 119 & 11.357 & Vanillin & 0.43 & 0.58 & - \\
\hline 120 & 11.462 & Isoeugenol & 0.16 & 1.02 & - \\
\hline 121 & 11.527 & Sinenofuranol & 0.18 & - & - \\
\hline 122 & 11.626 & 1-Decyne & 0.27 & 0.72 & - \\
\hline 123 & 11.965 & Homovanillyl alcohol & 2.56 & 2.78 & 0.08 \\
\hline 124 & 12.027 & Trans-Isoeugenol & 0.91 & - & - \\
\hline 125 & 12.544 & Allo-Inositol & 4.86 & 0.15 & - \\
\hline 126 & 13.017 & 5-tert-Butylpyrogallol & 1.71 & 1.71 & - \\
\hline 127 & 13.121 & 4-vinylsyringol & 1.10 & 1.04 & 0.17 \\
\hline 128 & 13.216 & 1,2-Anhydro-3,4,5,6-alloinositol & 0.84 & 4.26 & 0.08 \\
\hline 129 & 13.347 & Dodecanoic acid & 1.09 & - & - \\
\hline 130 & 13.557 & 4-vinyl-2,6-dimethoxyphenol & 1.34 & 0.19 & - \\
\hline 131 & 13.857 & Amol & 0.05 & - & - \\
\hline 132 & 13.935 & Unknown & 0.48 & - & - \\
\hline 133 & 14.106 & 3-Hydroxy-4-methoxycinnamic acid & 0.40 & - & - \\
\hline 134 & 14.204 & Senkyunolide & 0.32 & - & - \\
\hline 135 & 14.544 & 3-sulfanylheptanal & 0.21 & - & - \\
\hline 136 & 14.746 & 2,4-Dimethoxyphenol & - & 0.50 & - \\
\hline 137 & 14.910 & Methoxyeugenol & 0.71 & 0.37 & - \\
\hline 138 & 15.095 & Syringaldehyde; & 0.38 & 0.37 & - \\
\hline 139 & 15195 & (Z)-p-Methoxy-cinnamic acid & - & 1.32 & - \\
\hline 140 & 15.390 & $3,4,5$-Trimethoxyacetophenone & 0.20 & - & - \\
\hline 141 & 15.599 & Heptadecanoic acid & 0.06 & - & - \\
\hline 142 & 15.713 & Unknown & 1.14 & - & - \\
\hline 143 & 15.980 & Unknown & 0.16 & - & - \\
\hline 144 & 16.225 & Xanthoxylin & 0.81 & 1.1 & - \\
\hline 145 & 16.382 & Tetradecanoic acid & 0.66 & - & - \\
\hline 146 & 16.684 & Cerulignol & - & 0.19 & - \\
\hline 147 & 16.721 & Homosyringic acid & 1.80 & 2.40 & - \\
\hline 148 & 16.806 & Nonadecanol & 0.05 & - & - \\
\hline 149 & 17.314 & Unknown & 0.50 & - & - \\
\hline 150 & 17.399 & Unknown & 0.19 & - & - \\
\hline 151 & 17.828 & Cymol & 0.27 & - & - \\
\hline 152 & 18.146 & 2,4-Dimethoxybenzyl alcohol & 0.12 & - & - \\
\hline 153 & 18.284 & Lidocaine & 0.18 & - & - \\
\hline 154 & 18.337 & Hexadecanoic acid & 0.09 & 0.93 & - \\
\hline 155 & 18.451 & 2-Imidazolidinethione & - & - & 0.89 \\
\hline 156 & 18.700 & Unknown & 1.57 & - & - \\
\hline 157 & 28.922 & Plastoquinone 3 & - & 0.28 & 0.31 \\
\hline 158 & 29.193 & Tetrapentacontane & - & - & 3.18 \\
\hline 159 & 31.051 & Hexadecanoic acid, hexadecyl ester & - & - & 62.83 \\
\hline 160 & 31.606 & Unknown & - & - & 2.31 \\
\hline Total & - & - & 100 & 100 & 100 \\
\hline
\end{tabular}




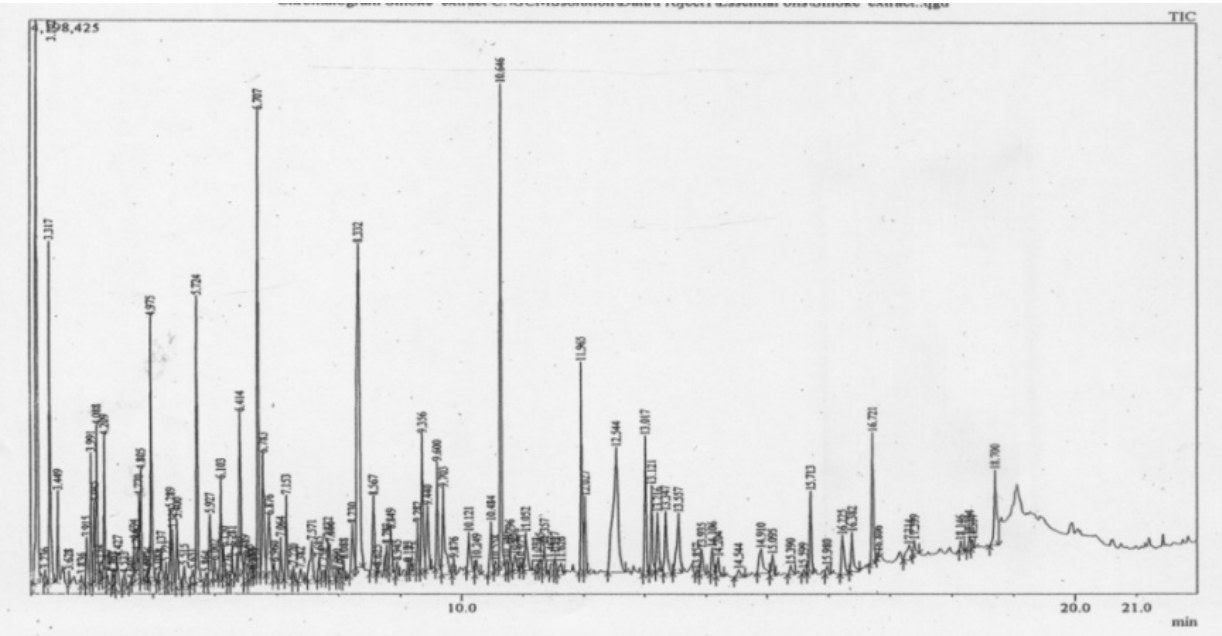

Fig. 1: GC-MS chromatogram of $A$. seyal stem dry distillate

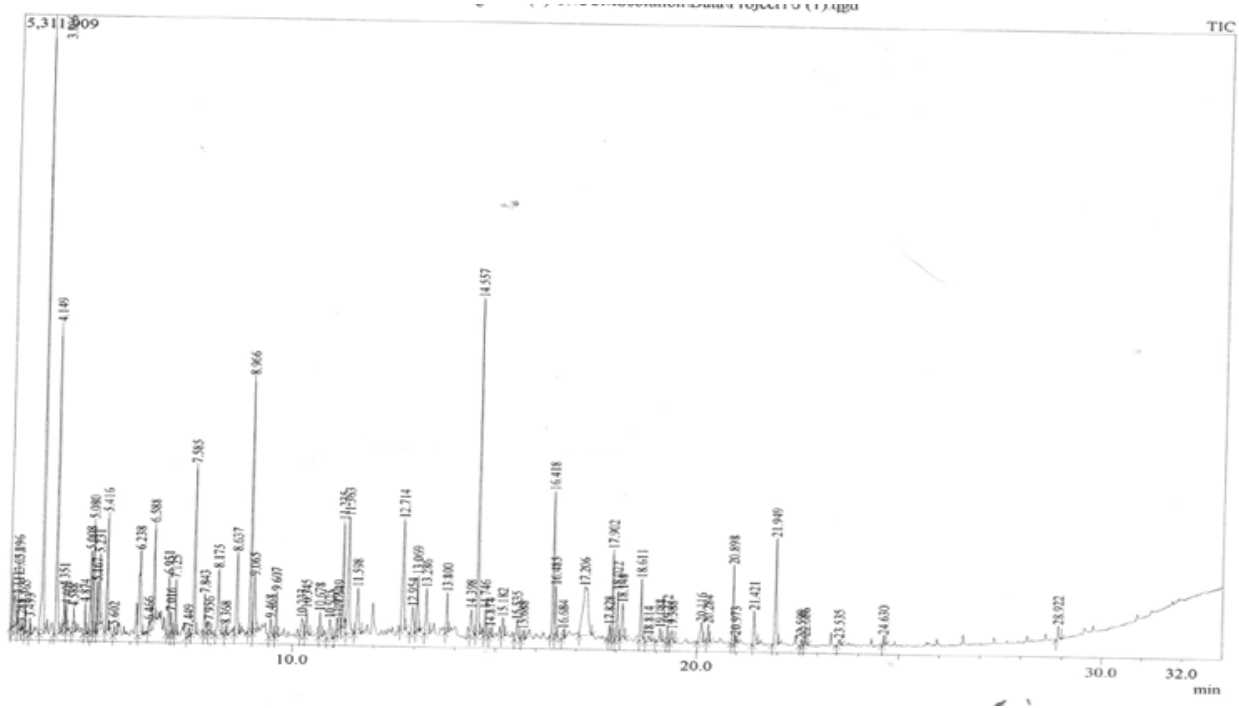

Fig. 2: GC-MS chromatogram of $A$. seyal stem wood dry distillate

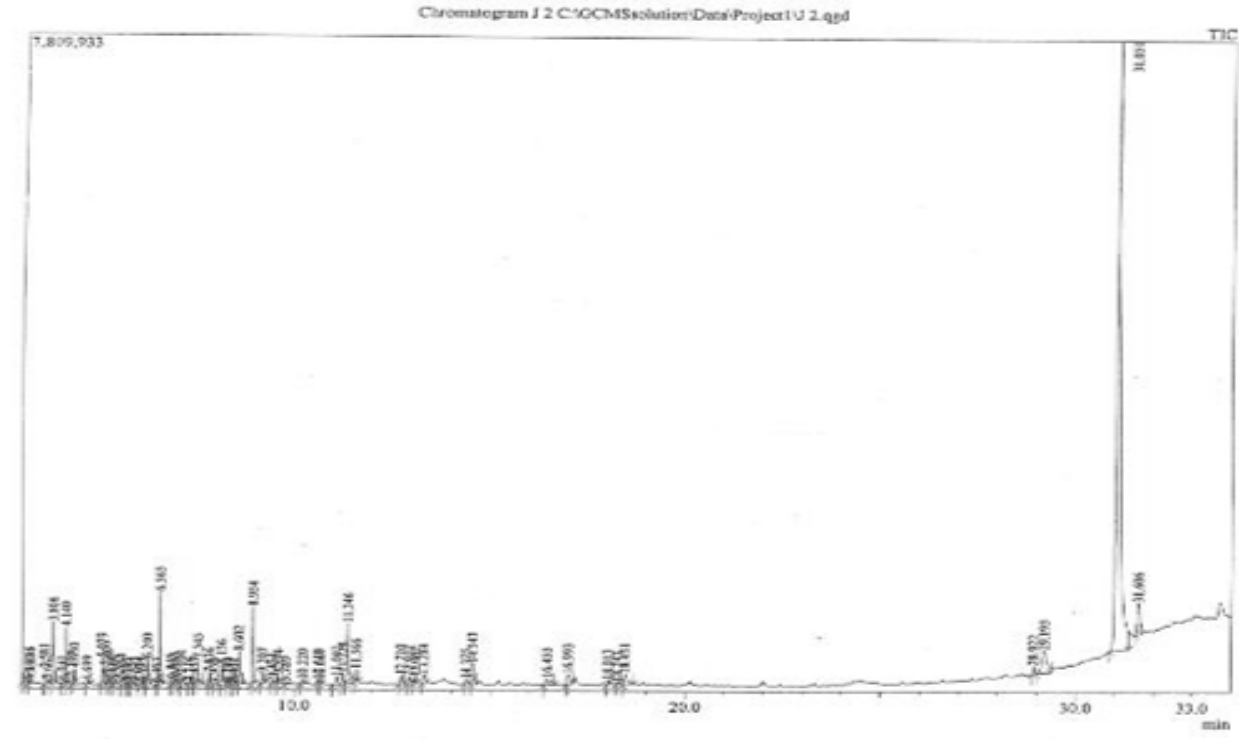

Fig. 3: GC-MS chromatogram of $A$. seyal stem bark dry distillate 


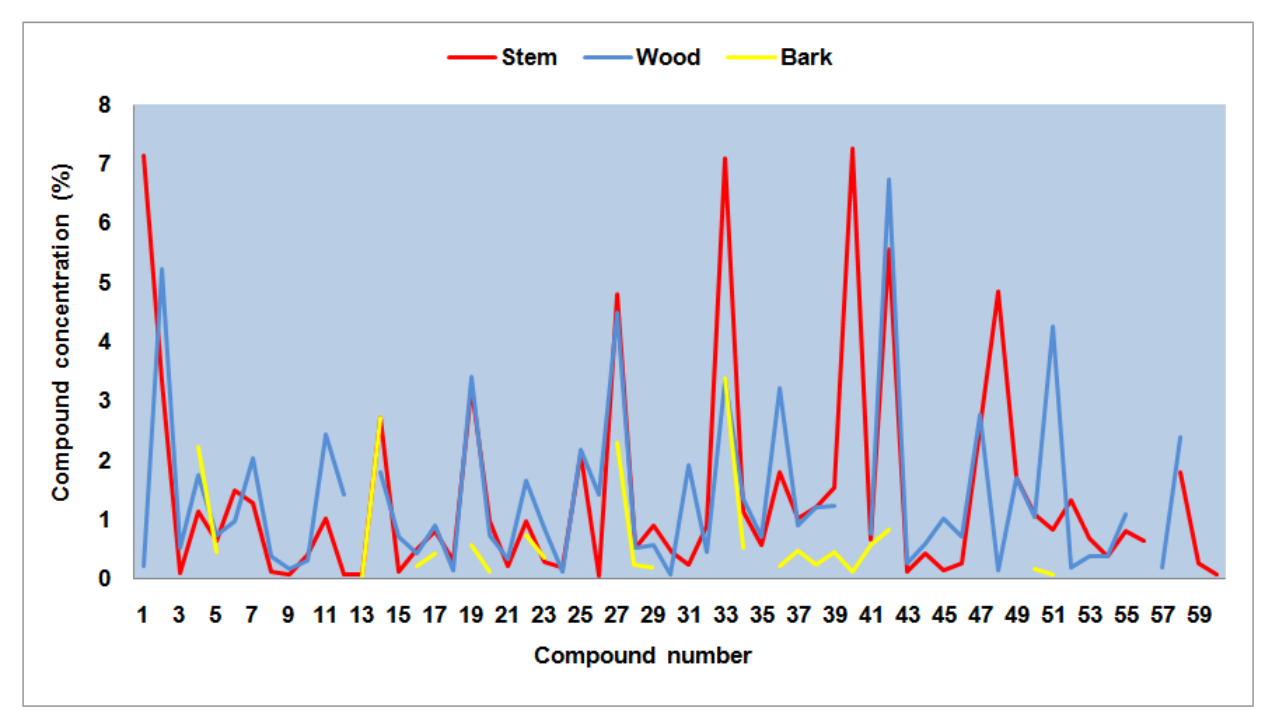

Fig. 4: The common and major compounds in the dry distillates of $A$. seyal stem, stem wood and stem bark 1-59= compounds number (table 3): 6,8,15,17,19,20,22,23,28,29,35,37,38,39,40,46,47,49,51,56,57,58,59,62,63,66,68,74,79,82,85,86,87,88,96,97,98,99,100,101, $103,108,110,119,120,122,123,125,126,127,128,130,137,138,144,145,146,147,148$

\section{DISCUSSION}

The various phytochemical compounds found in the plants are known to have beneficial importance in industrial and medical sciences [20]. The preliminary phytochemical analysis of $A$. seyal stem, stem wood and stem bark (table 1) revealed the presence of tannins, terpenoids, cardiac glycoside and reducing sugar in all assessed plant materials. Flavonoids, alkaloids and steroids are detected in the stem and stem wood, whereas, they are absence in the stem bark. Saponnins are not detected in any of the three plant materials. The results showed that the stem and stem wood parts which are traditionally used by Sudanese women [1] have the same secondary metabolites, whereas, the stem bark which is slightly used showed different in secondary metabolites. The presence of flavonoids, alkaloids, tannins, steroid, terpeniods, cardiac glycosides and reducing sugars are compatible with the secondary metabolites of Fabaceae family [21]. These findings are reported for the first time about the secondary metabolites of $A$. seyal stem, wood and bark.

The diverse health benefit of the plants is usually known to be through the numerous phytochemicals extractions [22]. The dry distillation of $A$. seyal stem and stem wood is well known for its medicinal and cosmetic values among the Sudanese women [3]. The dry distillates of $A$. seyal stem, stem wood and stem bark were found to be oily pale brown to red in color, with specific aromatic odor and water soluble. The distillates yields (table 2) were; $15 \% ; 14.1 \%$; $13.6 \%(\mathrm{v} / \mathrm{w})$ and $83.87 \% ; 48 \% ; 53 \%(\mathrm{w} / \mathrm{w})$ of the stem, stem wood and bark, respectively. Their specific gravity; refractive index; acid value; saponification value and ester value (table 2) were found to be $(0.95 \mathrm{~g}, 0.95,0.95)$; $(1.341,1.352,1.341) ;(23.6 \mathrm{ml} / \mathrm{g}, 24.6 \mathrm{ml} / \mathrm{g}$, $21.7 \mathrm{ml} / \mathrm{g}) ;(50.9 \mathrm{ml} / \mathrm{g}, 58.9 \mathrm{ml} / \mathrm{g}, 37.8 \mathrm{ml} / \mathrm{g})$ and $(34.8 \mathrm{ml} / \mathrm{g}, 34.3$ $\mathrm{ml} / \mathrm{g}, 16.1 \mathrm{ml} / \mathrm{g}$ ) in the stem, stem wood and bark respectively. The dry distillates of $A$. seyal stem and stem wood mainly used by Sudanese women [3] were found to be slightly different in their physiochemical properties, whereas, the physiochemical property of the slightly used distillate of stem bark is more different from that of stem and stem wood (table 2). These findings are reported for the first time about the percentage content and physiochemical properties of $A$. seyal dry distillates.

Regarding the GC-MS analysis, the difference between the chemical constituents of stem and stem wood distillates had been slightly, while, that of stem bark distillate was more difference from these two distillates (fig. 1, 2, 3, 4 and table 3). The identification of the constituents was done by the direct comparison of their retention times; peak areas; molecular weight; formula and fragmentation patterns according to the NIST library [19].
The analysis revealed the presence of many nitrogenous compounds which was compatible with the chemistry of the Fabaceae [20]. The dry distillate from the stem represented the presence of one hundred and twenty three constituents of which one hundred and seventeen of them have been identified, and the major constituents were found to be solerone $(7.27 \%)$, furfural $(7.15 \%)$, catechol (7.11\%), syringol (5.56\%), allo-inositol (4.86\%), mequinol $(4.81 \%)$ furfur alcohol (3.35\%), 3-methyl-1,2-cyclopentanedione (3.24\%), phenol (2.73\%), homovanillyl alcohol (2.56\%) and 3-cresol $(2.11 \%)$. the stem wood dry distillate was composed of eighty compounds, all of them have been identified with major compounds of 1,3 dimethyl-5-methoxypyrazol (10.61\%), syringol $(6.75 \%)$, furfur alcohol (5.24\%), mequinol (4.49\%), 1,2-anhydro-3,4,5,6-alloinositol (4.26\%), 3-methyl-1,2-cyclopentanedione (3.42\%), catechol (3.37\%), 3-methoxycatechol (3.22\%), homovanillyl alcohol (2.78\%) homosyringic acid (2.40\%), 3-cresol (2.18\%), 3-methyl-2cyclopentenone $(2.44 \%)$ and 1,2-cyclopentanedione $(2.03 \%)$. Sixty six compounds were detected in the dry distillate of the stem bark of which sixty-three have been identified and the main compounds were found to be hexadecanoic (62.83\%), catechol (3.38\%), tetrapentacontane $(3.18 \%)$, phenol $(2.72 \%)$, mequinol $(2.30 \%)$ and 2-ethylfurane $(2.22 \%)$. Some of the detected and identified compounds could be artefacts due to the process of dry distillation.

The main and common constituents found in the three distillates (fig. 4) were found to be proportional to their antioxidant and antimicrobial activity [1]. It is noteworthy to point out the relationship between these main constituents known of their antimicrobial and antioxidant properties and their content in the dry distillates. The different concentrations of these active constituents and their proportions in the three dry distillates explain clearly the potent antimicrobial activity of the stem [1] and its application in the fumigation traditions by Sudanese women. These findings about the chemical composition of $A$. seyal stem, stem wood and stem bark dry distillates are reported for the first time and adds to the current literature with regard to the presence of many nitrogenous compounds in the Fabaceae family [8] and abundance of essential oils, diterpenes, phytosterols and triterpenes in the Acacia genus.

\section{CONCLUSION}

These research conclude that the medicinal Sudanese Dokhan which is a fumigation process done by Sudanese women have good potential as sources of different bioactive compounds and antioxidants.

It is noteworthy to add that the chemical composition and content of detected components in the three dry distillates of the plant were 
proportional and comply with their uses in Sudanese traditional medicine. Sudanese women usually use stem wood for Dokhan, sometimes they use the stem and rarely the stem bark.

\section{AUTHORS CONTRIBUTION}

Design of the work was done by the first and second authors Dr. Ikram Mohamed Eltayeb and Dr. Itmad Awad Elhassan. Interpretation of data, writing and correction of the manuscript was done by the first author Dr. Ikram Mohamed Eltayeb. The experimental part of the work was done by Ms. Jihad Hasab Elrasoul and Ms. Eiman Salah Eldind.

\section{CONFLICT OF INTERESTS}

Declared none

\section{REFERENCES}

1. Ikram ME, Eiman SE, Jihad HE, Saad MHA. Comparative studies of antioxidant and antimicrobial activities of Acacia seyal stem, stem wood and stem bark dry distillates. Am J PharmTech Res 2016;6:440-50.

2. Abdalbasit AM, Noha MFM, Fatima ON, Alfatih AH. Ethnobotanical study of three trees: indigenous knowledge on trees used as cosmetic in khartoum state, sudan. Asian J Pharm Sci Tech 2014;4:178-82.

3. Orwa CA, Mutua A, Kindt R, Jamnadass R, Simon A. Agroforestree database: a tree reference and selection guide, version 4.0. Kenya: World Agroforestry Centre ICRA, Nairobi; 2009.

4. Weldegebriel, Berihe KK, Mulata H. Effect of feeding Acacia pods (Acacia seyal) with or without wheat bran on feed intake and digestibility of tigray highland sheep in hay based feed. J Biol Agric Health 2014;4:26-33.

5. Roothaert RL, Franzel S. Farmers preferences and use of local fodder trees and shrubs in Kenya. Agro Syst 2001;52:239-59.

6. Ikram ME, Eiman SE, Jihad HE, Saad MHA. Chemical composition, antioxidant and antimicrobial activities of Acacia seyal stem dry distillate. Int J Curr Res 2016;8:40010-6.

7. Shuttleworth S. The ancient history of Sudanese perfumes. African Aromatic South Africa; 2011. https://alisonbate.ca/ 2011/08/28/the-ancient-history-of-sudanese-perfumes/. [Last accessed on 02 Jul 2017]

8. M Wink. Evolution of secondary metabolites in legumes (Fabaceae). South Afr J Bot 2013;89:164-75.
9. Bodeker G, Ghat KKS, Burley J, Vantomme P. Phytomedicinal forest harvest in the United States. Med Plants 1997;11:147-58.

10. Fatou D, Diegane D, Agnieszka K, Antoine Le Q, Niokhor B, Dioumacor F, et al. Genetic and genomic diversity studies of Acacia symbionts in senegal reveal new species of mesorhizobium with a putative geographical pattern. J Plos One 2015;10:1371-91.

11. Brook I. The role of beta-lactamase-producing bacteria in obstetrical and gynecological infections. Gynecol Obstet Invest 199;32:44-50.

12. Farhat Al, Khan IH, Shahid F. Phytochemical screening of some Pakistanian medicinal plants. Mid-East J Sci Res 2011;8:575-8.

13. Prashant T, Bimlesh K, Mandeep K, Gurpreet K, Harleen K. Phytochemical screening and extraction: a review. Int Pharm Sci 2011;1:98-106.

14. Mosa EO, Hanadi HY, Justin DD, Remaz OM, Saad MH. General phytochemical screening and antioxidant activity of some sudanese medicinal plants. J Forest Prod Indus 2014;3:292-5.

15. World Health Organization. Quality control methods for medicinal plant materials. Geneva; 1998.

16. Michał L, Eugeniusz M. Modern technology of dry distillation of wood. Chemik 2011;65:1301-6.

17. British Pharmacopoei. Specific gravity determination A158, Refractive Index determination A157, Solubility determination A 11. TSO London 2002;20:1635-44.

18. British Pharmacopoei. Acid value determination A198, Saponification value determination A200, Ester value determination A198. TSO London 2002:20:1644-56.

19. NIST Standard Reference Database 69: NIST Chemistry Web Book. Available from: http://webbook.nist.gov/chemistry/. [Last accessed on 02 Jul 2017]

20. Benahmed-Bouhafsouna, Djied S, Mouzaz F, Kaid-Harche M. Phytochemical composition and in vitro antioxidant activity of chamaerops humilis 1. Extracts Int J Pharm Pharm Sci 2013;5:741-4.

21. Duarte MR, Wolf S. Anatomical characters of the phyllode and stem of Acacia podalyriifolia A. Cunn. ex G. don (Fabaceae). Brazil J Pharmacogn 2005;15:71-6.

22. Arunkumar K, KR Chandrashekar. Phytochemical evaluation and in vitro antimicrobial and antioxidant studies of leaf and stem bark extracts of Polyalthia fragrans (dalz.) bedd.-an endemic species of Western Ghats. Int J Pharm Pharm Sci 2017;9:20-4. 